\title{
PRIVATE PROSECUTION: A REMEDY FOR DISTRICT ATTORNEYS' UNWARRANTED INACTION
}

\begin{abstract}
"[N]o stronger or more effectual guarantee can be provided for the due observance of the law of the land, by all persons under all circumstances, than is given by the power, conceded to everyone by the English system, of testing the legality of any conduct of which he disapproves, either on private or on public grounds, by a criminal prosecution." 1 STEPHEN, History of the Crinsinal LaW 496 (1883).
\end{abstract}

DiSTRICT attorneys are required by statute to prosecute all matters of state concern. ${ }^{1}$ But since mechanical enforcement of all criminal laws is undesirable and impractical, ${ }^{2}$ the district attorney is accorded extensive discretion in the selection of criminals and crimes to prosecute. ${ }^{3}$ The decision not to prosecute can be implemented by mere inaction, ${ }^{4}$ acceptance of a compromise plea, ${ }^{5}$ or

1. A typical statute provides: "The prosecuting attorney shall commence and prosecute all civil and criminal actions in [his county] . . . in which the county or state may be concerned ...." Mo. ANn. Stat. $\$ 56.060$ (Vernon 1949). A few codes specify the prosecutor's duties with more imperative language. For example, Iowa CoDE ANN. $\S 336.2$ (1946) prescribes: "It shall be the duty of the county attorney to ... diligently enforce.... all the laws of the state ...."

2. Society's interests are frequently better served by warning than by prosecuting; obsolete laws should not be enforced. See Snyder, The District Attorney's Hardest Task, 30 J. Crni. L. \& Criminology 167, 168 (1939). In Commonwealth v. Dawson, 3 Pa. Dist. 603,604 (1894), the court commended the district attorney for refraining from prosecuting and added: "[Public welfare] ... may be advanced as much sometimes by leniency as by harshness, and a repetition of the offense may be more certainly prevented by withholding rather than inflicting punishment." The district attorney's decision to prosecute depends on the effect of the offense on the community, the means and time available in relation to other duties, the probability of accomplishing any practical results, and many other factors. See State ex rel. Bourg v. Marreo, 132 La. 109, 61 So. 136 (1913) ; Gould v. Parker, 114 Vt. 186, 42 A.2d 416 (1945). In addition, the limited capacity of available judicial machinery requires selection of offenses for trial. See Sly, California Judicial Council in Full Swing, 11 J. Am. Jub. Soc'y 9 (1927); The Judicial Conncil at Work, 1 Calif. B.J. 138 (1927); Law Assoctation of Philadelphia, Report of the Crimes SURVEY COMMISSION 408 (1926).

3. E.g., People ex rel. Schreiner v. Courtney, 380 Ill. 171, 43 N.E.2d 982 (1942) ; Engle v. Chipman, 51 Mich. 524, 16 N.W. 886 (1883) ; Commonwealth v. Nicely, 130 Pa. 261, 18 Atl. 737 (1889) ; Illinors Association for Criminal Justice, Illinois Crime Survey 270 (1929). "Arbitrary," "absolute" and "almost boundless" have been used to characterize the district attorney's discretion. Guiseppe v. Walling, 144 F.2d 608, 620 (2d Cir. 1944); Rowan v. Shawneetown, 378 Ill. 289, 38 N.E.2d 2 (1941); Brethorst v. Wylie, 205 Ill. App. 72 (1917). See also Attorney General v. Tufts, 239 Mass. 458, 132 N.E. 322 (1921) ; Gould v. Parker, 114 Vt. 186, 42 A.2d 416 (1945); Moley, The Administration of Criminal Justace IN MIssourr 20-21 (1926); Baker, The Prosecutor-Initiation of Prosecution, 23 J. Crins. L. \& Crinrnology 770 (1933); Caldwell, How to Make Prosecuting Effectual, 16 J. AM. JUd. Soc'y 73, 75 (1932).

4. Baker and DeLong have commented that the most frequent exercise of the prosecutor's discretion arises in decisions not to prosecute at all. Baker, supra note 3; Baker 
entry of a nolle prosequi. ${ }^{6}$ However, corruption, political ambition, ${ }^{7}$ or insufficiency of funds and personnel ${ }^{8}$ often motivate district attorneys to use these techniques to excess. Such abuse of the district attorney's discretion has created a substantial deficiency in criminal law enforcement. ${ }^{\circ}$ The United States

\& De Long, The Prosecuting Attorney-Power and Duties in Criminal Prosecution, 24 I. CRIM. L. \& CRIMINOLOGY 1025, 1064 (1934). The incidence of unprosecuted crime was dramatized by the four reports of the Kefauver Crime Committee. Special Committee to Investigate Organized Crime in Interstate Commerce, Interim Report, S. RER. No. 2370, 81 st Cong., 2d Sess. (1950) ; id., Second Interim Report, S. Rep. No. 141, 82d Cong., 1st Sess. (1951) ; id., Third Interim Report, S. REp. No. 307, \$2d Cong., 1st Sess. (1951); id., Final Report, S. Rep. No. 725, 82d Cong., 1st Sess. (1951) (hereinafter cited as Kcfauvir Committee Reports). For example, see Kefauver Committee Second Interim Report 3, 26; Kefauver Committee Third Interim Report 2, 6, 34, 68, 84, 106-09, 181-\$2.

5. Through the compromise plea, crimes such as robbery, burglary and rape are reduced to petty larceny, assault and battery, and contributing to the delinquency of a minor. Those who plead guilty to the lesser offense receive as little as thirty days in the county jail while the crimes committed carry penalties of twenty years to life. Dash, Cracks in the Fonndation of Criminal Justice, 46 ILL. L. REv. 385, $392-93$ (1951).

6. At common law, the public prosecutor could enter a nolle prosequi at any time before the empaneling of the jury or after the return of the verdict. United States $v$. Brokaw, 60 F. Supp. 100 (S.D. IIl. 1945). Historically, it was intended for infrequent use; the contrary result has followed. Moley, Politics and Crininal Prosecution 150-53 (1929). See note 7 infra. Most jurisdictions today retain the prosecutor's common law power to use the nolle. See, e.g., United States v. Brokaw, supra; People $c x$ rcl. Attorney General v. District Court, 23 Colo. 466, 48 Pac. 500 (1897); Orabona v. Lindscott, 49 R.I. 443, 144 Atl. 52 (1928).

7. Pound, Crininal Justice In America 185-86 (1929); Steinderg, Crininal Prosecution In CONNECTrCUt 58 (unpublished manuscript in Yale Law Library 1940); Hobbs, Prosecutor's Bias, An Occupational Disease, 2 Ala. L. Rev. 40, $45-47$ (1949); Kennedy, Lacal Politics vs. Prosecuting Attorney, 23 J. Ar. Jud. Soc’y 180 (1940) ; Caldwell, supra note 3, at 74-75. Evidence gathered by the Kefauver Committee indicating corruption is presented in material cited note 4 supra. Moley contends that use of the prosecutor's office as a stepping stone to higher political office is demonstrated by the fact that $42 \%$ of the lawyers in Congress in 1914, 1920 and 1924 and in governorships from 1920 to 1924 had been prosecuting attorneys. One prosecutor rose through the political ranks so rapidly that he was able to exercise the governor's discretion to refuse a pardon to a convict he prosecuted. Moley, Polirics and Criminal Prosecution 76-79, 157-60 (1929).

8. Over $25 \%$ of 151 public prosecutors from 45 states who responded to a Yale Law Journal questionnaire on prosecution procedures stated that they did not have enough time or help to conduct necessary prosecutions. These replies to 300 questionnaires circulated to public prosecutors in all 48 states are on file in the Yale Law Library. Results of this survey, hereinafter cited as QuEsTIONNAIRE, are reported in the text at notes $52,60,64$, $68,116,131$ infra.

The prosecutor's pay is low, and often only inexperienced and incompetent men can be attracted. U.S. National CoMmission on Law Observance and EnFORCEMENT, Report on Prosecutron 15 (1931) (hereinafter cited as Report on Prosecution); What Is Wrong With the Prosecutor?, 11 J. Axr. Jud. Soc'y 67 (1927). A study of Missouri prosecutors disclosed that most of them ranged in age from 25 to 29 years, and had had from 1 to 4 years' experience at law before election. Moley, Administration of Criminal JUSTICE IN MISSOURI 21 (1926).

9. Excessive and irresponsible use of the nolle prosequi and compromise plea demonstrates this deficiency. Surveys of criminal prosecutions in Illinois, Missouri, Georgia and 
National Commission on Law Enforcement concluded that the majority of suspects are never brought to trial for their alleged crimes even though there are convincing cases against them. ${ }^{10}$ More recently the Kefauver Crime Commission has charged that prosecutors in general are failing to suppress widespread crime.11

Experience has conclusively demonstrated that existing methods for control of the district attorney's discretion are inadequate. District attorneys may be removed by courts, governors, legislatures and voters, ${ }^{12}$ but these restraints

Cleveland disclose excessive use of the nolle prosequi. Illinors Assoctation for Crimrinal Justice, Illinois Crime Survey 269-72 (1929); Missouri Assoctation for Criminal Justice, Missouri Crime Survey 274, 276 (1926); Crime and the Georgia Courts, 16 I. Crim. L. \& Criminology 169 (1925) ; Cleveland Foundation Survey, Crminal Justice in Clevveland 142-46 (1922). The California Crime Commission reported that compromise of criminal cases creates serious law enforcement problems. Califorinia Crime Cominssion Report 27 (1929). The U.S. National Commission reported on the basis of these and other surveys that methods for selecting cases to prosecute were haphazard and careless. Report on Prosecution, op. cit. supra note 8 , at 100 . The persistent excessive use of the nolle and compromise plea was demonstrated by statistics disclosing that for over a quarter of a century in Chicago, $22 \%$ of all indictments were disposed of by waiving the felony and prosecuting on a lesser included charge. Molex, Politrcs and Crninnad Prosecutron 183 (1929). Statistics compiled in Clark \& Shulman, Law AdminnisTRATION IN CONNECTICUT, table CXvi, insert at 185 (1937), disclose widespread use of the nolle prosequi.

Figures of a more recent vintage substantiate these statistics. A study of criminal prosecutions in the Municipal Court of Chicago for 1948, 1949 and 1950 revealed that approximately $32 \%$ of all felony cases are disposed of by the nolle and about $34 \%$ by the lesser plea. Dash, supra note 5 , at 392.

The small percentage of apprehended suspects brought to trial led one observer to quip that if Ali Baba and his forty thieves were caught in the United States, only six would be prosecuted. John M. Love, quoted in MoLeY, op. cit. supra, at 27.

10. Report on Prosecution, op. cit. supra note 8, at 11.

11. Kefauver Committee Third Interin Report 67-68, 181; Kefauver Committee Final Report 42-76.

12. For state statutes authorizing judicial removal of the prosecutor, see, e.g., Mont. Rev. Codes Ann. \$ 94-5516 (1947) ; N.M. Stat. Ann. § 17-1-9 (1953); Ohio Gen. Code Awn. $\$ 291$ (1951). Also see, De Long \& Baker, The Prosecuting Attomey-Provisions of Law Organizing the Office, $23 \mathrm{~J}$. Crim. L. \& Crimsnorogy 926, 953-54 (1933). In Attorney General v. Pelletier, 240 Mass. 264, 134 N.E. 407 (1922), and Attorney General v. Tufts, 239 Mass. 458,132 N.E. 322 (1921), the Massachusetts Supreme Judicial Court removed district attorneys under the provisions of Mass. ANN. Laws c. 211, $\$ 4$ (1951). Analogous power is vested in New Jersey Superior Court justices through their authority to require the attorney general to supersede the prosecutor of the pleas in the county courts. N.J. Stat. ANN. \& 52:17A-4f (1955). A predecessor of this statute was applied in State ext rel. O'Reardon v. Wilson, 4 N.J. Misc. 1008, 135 Atl. 280 (Sup. Ct. 1926).

Other state statutes grant the governor power to remove public prosecutors. E.g., Minn. Stat. Ann. $\$ 351.03$ (West 1947) ; N.Y. Const. art. 9, § 5; WIS. Stat. § 17.11 (1953). Removal of the public prosecutor by the governor was upheld in State ext rel. Hardee v. Allen, 126 Fla. S78, 172 So. 222 (1937) ; State ex rel. Kinsella v. Eberhart, 116 Minn. 313, 133 N.W. 857 (1911).

On a recommendation of the attorney general, two-thirds of the Maryland Senate may remove a state's attorney. Mp. Const. art. 5, § 7. In Tennessee, the district attorney may 
are ineffective to control abuses of discretion. The district attorney need fear ouster only for criminal activity, and even where evidence of such conduct exists, ouster proceedings are seldom employed. ${ }^{13}$ Similarly, the authority of state officials to supersede the local prosecutor has rarely been exercised. ${ }^{14}$ This method of restraint merely places the ultimate opportunity for action with other, busier, more remote officials. ${ }^{\text {I5 }}$ Even when confronted with evidence of flagrant inaction by local prosecutors, state officials have not used their powers of supersedure. ${ }^{16}$ The prosecutor's domination of the grand jury and his power

be impeached whenever a majority of the House of Representatives believes he is guilty of a crime. Tenn. CodE ANn. \$ 11864 (Williams 1934).

Twelve states have provisions for recall of the public prosecutor. De Long \& Baker, The Prosecuting Attomey-Provisions of Law Organizing the Office, $23 \mathrm{~J}$. CRIs. L. \& CRIMINOLOGY 926, 954 (1933).

13. See Moley, Politics and Criminal Prosecumon 144 (1929); De Long \& Baler, The Prosecuting Attomey-Provisions of Law Organizing the Office, $23 \mathrm{~J}$. CRIM. L. \& CrIminology 926, 957, 963 (1933). Binkley, The Prosecuting Attorney in Ohio-An Obsolete Office, 18 NaT'L Munic. Rev. 569, 572 (1929), succinctly characterizes the prosecutor's security: "If he is merely lazy or utterly incompetent, his position is simply impresnable." See also Caldwell, How To Make Prosecuting Effectual, 16 J. Anr. Jub. Soc'r 73, 75-76 (1932).

14. Many jurisdictions permit state officials to supersede the district attorney. Several states have expressly given the attorney general and the local prosecutor concurrent jurisdiction to conduct criminal actions. E.g., CAL. CoNsT. art. V, $\$ 21$; CAL. ConE Gov. $\$ 12550$ (1951) ; LA. Rev. Stat. ANn. \$ $15: 23$ (West 1951) ; Neb. Rev. Stat. \$ \$4-204 (1943). Mlany jurisdictions give the attorney general authority to supervise the local prosecuting attorney. E.g., Iowa Code ANn. $\$ 13.2(7)$ (1946); N.H. Rev. Laws c. $24, \$ 5$ (1942); Wash. REv. CoDE $\$ 43.10 .090$ (1951). Under such statutes the attorney general has conducted criminal prosecutions. Mundy v. McDonald, 216 Mich. 444, 185 N.W. 877 (1921); State ex rel. Nolan v. District Court, 22 Mont. 25, 55 Pac. 916 (1899); State $c x$ rel. Miller v. District Court, 19 N.D. 819, 124 N.W. 417 (1910). Several states authorize the attorncy general to supersede the local prosecutor at the request of the governor. E.g., N.Y. Exec. $\S 63(2)$; W. VA. Code ANn. $\$ 260$ (1955) ; People v. Gibson, 53 Colo. 231, 125 Pac. 531 (1912) ; State v. Bowles, 70 Kan. 821, 79 Pac. 726 (1905). The Pennsylvania Supreme Court has held that the attorney general has a common law power to supersede the local prosecutor. Margiotti Appeal, $365 \mathrm{~Pa} .330,75 \mathrm{~A} .2 \mathrm{~d} 465$ (1950); Commonwealth ex ril. Minerd v. Margiotti, $325 \mathrm{~Pa} .17,188$ Atl. 524 (1936). The attorney general's power to conduct criminal prosecutions has been carried to its logical conclusion in the formation of the California State Department of Justice. For discussion of this Department, see Beasley, California Unifies Enforcement Agencies to Fight Crime, 20 A.B.A.J. 757 (1934); Warren, A State Department of Justice, 21 A.B.A.J. 495 (1935).

15. For criticism of the attorney general's effectiveness in criminal prosecutions, see De Long, Powers and Duties of the State Attorney-General in Criminal Prosccution, 25 J. CrRs. L. \& Crinunology 358, 397-99 (1934) ; Bettman, Centralization of State Prosecuting Agencies, 1 Ohio Op. 223 (1934).

16. The Kefauver Committee reported numerous instances where state officiais failed to take action to enforce the law. Despite widespread crime around New Orleans Parish, state officials refused to act. Kefauver Committee Third Interim Report 84-90. In Louisiana, the attorney general can supersede district attorneys. LA. Rev. Stat. ANn. $\$ 15: 23$ (West 1951). The Committee condemned Governor Fuller Warren of Florida for reinstating the sheriff of Dade County without a full investigation. Kefauver Committee Third Interin Report 36. Governor Warren was further criticized for not responding to pleas to suppress 
to nolle its indictments preclude those jurors from making effective inroads on his discretionary decisions. ${ }^{17}$ Direct communication with the grand jury by private complainants is prohibited in most states, ${ }^{18}$ and even where permitted, it is discouraged in some states by the threat of a contempt citation for wasting the jury's time. ${ }^{19}$ Aroused public opinion has been unable to induce prosecution even where law enforcement is outrageously inadequate. ${ }^{20}$

Existing judicial restraints have also proved ineffective. ${ }^{21}$ Courts consistently refuse to issue a mandamus to compel criminal prosecutions, ${ }^{22}$ since the

gambling in Hollywood, Florida. Kefalver Committee Final Report 75. Under Fla. Stat. Anv. $\$ 27.14$ (1943), the governor may replace the state's attorney. The Mississippi Governor refused to take any action against "wide open" gambling in Harrison County, Mississippi, when petitioned by local citizens. Kefauver Comnnitfee Third Interim Report 84. Open and notorious gambling in New York and New Jersey was also reported. Kefauver Conmittee Second Interin Report 3; Kefauver Committee Third Interim Report 106-08. No action was taken by state officials although they had the power to do so. N.Y. ExEc. \$ 63(2) ; N.Y. Const. art. 9, § 5; N.J. Stat. ANv. \$ 2:182-1. (1939).

The Kefauver Committee suggested that state officials as well as local prosecutors are susceptible to corrupt influences. The Committee termed testimony given by Missouri's Governor Smith about his connection with racketeers as "simply not credible." Kefanver Committe Third Interim Report 40. A report made by Governor Dewey's counsel and submitted to the Committee was labeled false. Id. at 108. Governor Fuller Warren of Florida was frequently criticized for questionable activities in relation to law enforcement. Kiffauver Committee Final Report 76. Also see note 20 infra. The Committee further indicated that the California State Department of Justice was used to organize a system of statewide gambling protection with the apparent blessing of the attorney general. Kefautver Conmittce Second Interinn Report 26-27.

17. See Brack v. Wells, 184 Mid. 86, 40 A.2d 319 (1944); Moley, Politics AND Criminal Prosecution 50, 127 (1929) ; Binkley, The Prosecuting Attorney in Ohio-An Obsolcte Office, is NaT'L Munic. Rev. 569, 571. (1929); note 6 supra.

18. Charge To Grand Jury, 30 Fed. Cas. 992, No. 18255 (C.C.D. Cal. 1872) ; McCullough v. Commonwealth, $67 \mathrm{~Pa} .30$ (1870); State v. Love, 23 Tenn. 255 (1843). Contra, In rc Lester, $77 \mathrm{Ga} .143$ (1886).

19. People v. Parker, 374 Ill. 524, 30 N.E.2d 11 (1940) ; Hitzelberger v. State, 173 Md. 435, 196 Atl. 288 (1938) ; Commonwealth v. McNary, 246 Mass. 46, 140 N.E. 255 (1923).

20. An aroused public was unable to induce action by public prosecutors in Miami, Hollywood or Tampa, Florida, Covington, Kentucky, Harrison County, Mississippi, or in the New Orleans, Louisiana area. Kefauver Committee Interim Report 10; Kefauver Committee Third Intcrim Report 83-84; Kefauver Committee Final Report 43-44, 7576. It is of course not easy to arouse public attention, even where repeated instances of flagrant abuse have occurred. Openly corrupt prosecutors have on occasion won reelection. See Attorney General v. Tufts, 239 Mass. 458, 488, 132 N.E. 322 (1921); State v. Graves, 346 Mo. 990, 144 S.W.2d 91 (1940).

21. Most jurisdictions consider the public prosecutor's discretion to be beyond the court's control. E.g., United States v. Brokaw, 60 F. Supp. 100 (S.D. I11. 1945); State cox rel. Spencer v. Criminal Court, 214 Ind. 551, 15 N.E.2d 1020 (1938); Wilson v. County, 257 I1l. App. 220 (1930). Contra, Ex parte Hayter, 16 Cal. App. 211, 116 Pac. 370 (1911); Commonwealth $e x \mathrm{rel}$. Attorney-General v. Hipple, $69 \mathrm{~Pa} .9$ (1881).

22. In dicta the courts often suggest that a public prosecutor may be compelled to act, but petitions to force criminal prosecution are nevertheless refused. Patten v. Dennis, 134 F.2d 137 (9th Cir. 1943) ; Ackerman v. Houston, 45 Ariz. 293, 43 P.2d 194 (1935) ; Brack 
impossibility of following the district attorney through the case reduces this device to a futile gesture. ${ }^{23}$ Efforts to provide judicial supervision of the nolle prosequi and the compromise plea have failed. ${ }^{24}$ While judicial power to appoint a substitute if the public prosecutor is unavailable or disqualified has somewhat curtailed the district attorney's discretion, ${ }^{25}$ in most states this power

v. Wells, 184 Md. 86, 40 A.2d 319 (1944). In the only reported case where the district attorney was compelled to prosecute criminally, the mandamus action was instituted by the attorney general. Commonwealth ex rel. Attorney-General v. Hipple, supra note 21 . That case raises the issue of a state official's power to control the district attorney. See note 14 supra.

However, occasionally mandamus has been issued to compel the district attorney to perform civil duties. Board of Supervisors v. Simpson, 36 Cal. 2d 671, 227 P.2d 14 (1951) (mandamus issued to compel the district attorney to abate a nuisance); Thomas v. Fuller, 166 La. 847, 118 So. 42 (1928) (mandamus issued to compel the public prosecutor to institute quo warranto actions) ; State ex rel. Brown v. Warnock, 12 Wash. $2 \mathrm{~d} 478,122$ P.2d 472 (1942) (same) ; State ex rel. Cook v. Richards, 61 S.D. 28, 245 N.W. 901. (1932) (state's attorney compelled to challenge county commissioner's redistricting of election units). But the courts are even reluctant to compel public prosecutors to perform civil duties. See, e.g., Buggelin v. Doe, 8 Ariz. 341, 76 Pac. 458 (1904) ; Vanhoose v. Yingling, 172 Ark. 1009, 291 S.W. 420 (1927) ; People ex rel. Miller v. Fullenwider, 329 IIl. 65, 160 N.E. 175 (1928) ; Herman v. Morlidge, 298 Ky. 632, 183 S.W.2d 807 (1944) ; Everding v. McGinn, 23 Ore. 15, 35 Pac. 178 (1889).

23. Boyne v. Ryan, 100 Cal. 265, 34 Pac. 707 (1893) ; People ex rel. Staats v. Tremain, 29 Barb. 96, 17 How. Pr. 10 (N.Y. Sup. Ct. 1859) ; State ex rel. Rosbach v. Pratt, 63 Wash. 157, 122 Pac. 987 (1912).

24. Some states attempted to curtail compromises by requiring the district attorney to submit his reasons for recommending the lesser plea to the court. Minn. Stat. AnN. $\S 630.30$ (West 1947) ; N.Y. CRIMr. ConE $\$ 342$ (a). Similarly, a minority of jurisdictions abridged the prosecutor's common law power to enter a nolle by requiring court assent before it could become final. E.g., People ex rel. Hayne v. Newcomer, 2S4 I11. 315, 120 N.E. 244 (1918) ; Halloran v. State, 80 Ind. 586 (1881) (dictum) ; Denham v. Robinson, 72 W. Va. 243, 77 S.E. 970 (1913). In both situations court approval became a mere formality. In REPORT oN PROSECUTION, op. cit. supra note 8 , at 19, the role of the courts in supervising the nolle prosequi was evaluated as perfunctory and achieving little. Weintraub \& Tough, Lesser Pleas Considered, 32 J. Crmi. L. \& Crininology 506, 518-21 (1942), reported the results of a detailed study on the effectiveness of the New York law requiring the district attorney to submit his reasons and receive court approval before entering a compromise plea. For the most part routine reasons were given, and in many cases no reason at all. Weintraub and Tough found that the judiciary plays an insignificant role in the regulation of compromise pleas. They concluded that the New York statute was not a deterrent to the acceptance of the compromise plea. Id. at 529 .

25. The court's power to appoint a substitute if the public prosecutor is unavailable or disqualified has been based on inherent or statutory authority or both. E.g., Pelaez v. State, 107 Fla. 50, 144 So. 364 (1932) ; Sayles v. Circuit Judge, 82 Mich. 84, 46 N.W. 29 (1890); State v. Gauthier, 113 Ore. 297, 231 Pac. 141. (1924). The prosecutor has been held to be unavailable for a variety of reasons. Glavino v. People, 75 Colo. 94, 224 Pac. 225 (1924) (absent from court sessions); White v. Polk County, 17 Iowa 413 (1864) (absent from the state) ; Territory v. Harding, 6 Mont. 323, 12 Pac. 750 (1S87) (absent from the county); Mahaffey v. Territory, 11 Okla. 213, 66 Pac. 342 (1901) (physically infirm); State v. Smalls, 98 S.C. 297, 82 S.E. 421 (1914) (sickness) ; State v. Smith, 117 W. Va. 598, 186 S.E. 621 (1936) (pressure of other work). Other factors have caused the prosecutor 
cannot be used to remedy failure or refusal to prosecute. ${ }^{26}$ Even where available, ${ }^{27}$ replacement for inaction is not adequate because there is no advocate who can present evidence of improper conduct, challenge the prosecutor's judgment, and assume responsibility for conducting the prosecution if the court decides to replace the district attorney. ${ }^{28}$

Supplementing judicial replacement power with private prosecution would remedy the deficiencies of that restraining technique and provide a practical method for curtailing abuses of the district attorney's discretion. The core of this plan is judicial supervision of the prosecutor's discretionary acts. Following a showing by a private citizen that the public prosecutor has abused his discretion through inaction or improper action, the court would have the power to appoint a privately hired attorney to act as the public prosecutor for a single action. This plan appears to offer a promising solution to the delicate dilemma posed by divergent demands for independence and control of the public prosecutor.

\section{Judicial Replacement of the District Attorney}

Seven jurisdictions currently allow the courts to appoint a substitute prosecutor to replace the district attorney for a single criminal action if he fails or refuses to prosecute. ${ }^{29}$ The Pennsylvania statute also permits substitution if the prosecutor proceeds improperly. ${ }^{30}$ In two states the constitution is the source of the replacement power $;^{31}$ the others rely on statutes or inherent judicial authority. ${ }^{32}$ The few appellate cases involving judicial replacement

to be held disqualified. People v. Walters, 98 Cal. 138, 32 Pac. 864 (1893) (previous service by prosecutor as defendant's attorney); People v. Morretti, 349 I1l. App. 67, 109 N.E.2d 915 (1952) (prosecutor appeared in same case as a witness) ; State v. Jones, 306 Mo. 437, 268 S.W. $\$ 3$ (1924) (simultaneous civil suit between prosecutor and accused); State ex rel. McGrade v. District Court, 52 Mont. 371, 157 Pac. 1157 (1916) (removal proceedings against prosecutor) ; State ex rel. Thomas v. Henderson, 123 Ohio St. 474, 175 N.E. $\$ 65$ (1931) (prosecutor under investigation).

26. Mahaffey v. Territory, supra note 25 ; State v. Heaton, 21 Wash. 59, 56 Pac. 843 (1899). Contra, Spaulding v. State, 61 Neb. 289, 85 N.W. 80 (1901).

27. A few states permit courts to replace the district attorney for failure or refusal to prosecute. Minn. Stat. Ann. \$ 388.12 (West 1947) ; N.D. Cods \$ 11-1606 (1943) ; PA. Stat. Ann. tit. 16, \$3432 (1930); Tenn. Const. art. 6, \$ 5; Utam Const. art. 8 , \$ 10; Taylor v. State, 49 Fla. 69, 38 So. 380 (1905); Territory v. Harding, 6 Mont. 323, 12 Pac. 750 (18S7) (dictum).

28. Judges feel it is inappropriate for them to become involved as partisans. When Judge Goodenough of Kenton County, Kentucky, was asked by the Kefauver Committee why he did not take an active lead in suppressing crime, he replied: "Now my conduct, of necessity, must be restricted. I am a judge, Sir." Kefauver Committee Final Report 47. See also Taylor v. State, 49 Fla. 69, 91, 38 So. 380, 387 (1905) (dissenting opinion).

29. See note 27 sitpra.

30. Pa. Stat. Ann. tit. 16, \$ 3432 (1930).

31. Tenn. Const. art. $6, \S 5$; Utan Const. art. $8, \$ 10$.

32. Mrnn. Stat. Ann. $\$ 388.12$ (West 1947) ; N.D. Code $\$ 11-1606$ (1943) ; Pa. Stat. AnN. tit. 16, § 3432 (1930) ; Taylor v. State, 49 Fla. 69, 38 So. 380 (1905) ; Territory v. Harding, 6 Mont. 323, 12 Pac. 750 (1887) (dictum). 
for abusive action or inaction contain little to indicate what factual situations will justify use of the replacement power. The case law reveals that as a general rule the district attorney will be replaced only when there is a vigorous difference of opinion between court and prosecutor regarding the advisability of prosecution. ${ }^{33}$ In addition, it has been indicated that the district attorney's discretionary acts will be rigorously scrutinized if there is some suggestion of interest on his part. ${ }^{34}$ But while instances of judicial replacement of the prosecutor are infrequent, the case law does provide some indication of both the constitutionality and limitations on the use of this power.

\section{Constitutionality of the Replacement Power}

Statutes authorizing judicial replacement of the district attorney may encounter constitutional objections in the thirty-eight states where the office of the public prosecutor is established or regulated by the state constitution. ${ }^{35}$ While the Pennsylvania court has sustained the constitutionality of a replacement statute, ${ }^{36}$ the South Dakota court has held that such a statute abridged a constitutional provision establishing the office of the public prosecutor. ${ }^{37}$ The North Dakota court has raised the additional objection that grounds for removal of the public prosecutor specified in its constitution are exclusive and may not be supplemented by statute. ${ }^{38}$

Constitutional provisions which establish the office of the public prosecutor pose no real problem where the statute permits replacement only when a district attorney has abused his discretion. All courts which have considered the duties of a district attorney have held that his constitutional authority to prosecute is discretionary. ${ }^{39}$ A necessary corollary of this holding is the proposition that the right can be enjoyed only so long as the discretion is not abused. ${ }^{\circ}$ Therefore, whenever a district attorney has abused his discretion in electing not to prosecute, he is acting beyond the bounds of his authority, whether or not that authority was vested in him by a constitution. In such a case, the legislative

33. Commonwealth v. Dawson, 3 Pa. Dist. 603 (1894) ; Pippin v. State, 34 Tenn. 43 (1854) ; Moreland v. State ex rel. McCray, 168 Tenn. 145, 76 S.W.2d 319 (1934).

34. Commonwealth v. McHale, 97 Pa. 397 (1881).

35. Thirty-eight state constitutions provide for a prosecuting attorney. While some constitutions merely contain a mandate to the legislature to establish the office of the public prosecutor, others provide for his election, term of office, salary, removal and territory under his jurisdiction. De Long \& Baker, The Prosecuting Attorney-Provisions of La*' Organizing the Office, $23 \mathrm{~J}$. CRMr. L. \& Crumnology 926, 928-30 (1933).

36. Commonwealth v. McHale, $97 \mathrm{~Pa} .397$ (1881).

37. State v. Flavin, 35 S.D. 530, 153 N.W. 296 (1915).

38. See State ex rel. Ilvedson v. District Court, 70 N.D. 17, 291 N.W. 620 (1940).

39. E.g., People v. Courtney, 380 I11. 171, 43 N.E.2d 982 (1942) ; Engle v. Chipman, 51 Mich. 524, 16 N.W. 886 (1883) ; Commonwealth v. Nicely, 130 Pa. 261, 18 Atl. 737 (1889). See also note 3 supra.

40. Commonwealth ex rel. Attorney-General v. Hipple, 69 Pa. 9 (1881) ; Patten v. Dennis, 134 F.2d 137 (9th Cir. 1943) (dictum) ; Ackerman v. Houston, 45 Ariz. 293, 43 P.2d 194 (1935) (dictum) ; Brack v. Wells, 184 Md. 86, 40 A.2d 319 (1944) (dictum). 
power to provide for law enforcement can properly be used to permit judges to replace irresponsible prosecutors. Indeed, some courts have asserted that they possess inherent power to do this, unaided by statutory authorization. ${ }^{41}$

The decisions of the Pennsylvania and South Dakota courts both conform to this analysis. The Pennsylvania court allowed replacement where a district attorney abused his discretion, stating that the constitutional provision establishing the prosecutor's office was a bar only to abolition of the office. ${ }^{42}$ The South Dakota court invalidated a replacement statute because the law authorized replacement not only when discretion was abused, but whenever "in the opinion of the court the ends of justice would be promoted thereby."43 Since this statute allowed replacement without requiring a showing that the district attorney was acting beyond his constitutionally guaranteed authority, it was properly held to conflict with the state constitution.

Constitutional provisions which authorize removal of a district attorney for specified reasons also do not limit the judicial power to replace for abuses of discretion. Conduct which constitutes an abuse of discretion is still beyond the authority of a district attorney irrespective of whether he may also be removed for corruption, habitual drunkenness, incompetency or malfeasance. ${ }^{44}$ Clearly the intent of such provisions was to insure that the grounds enumerated would be held sufficient to authorize removal, and not to imply that abuse of discretion was to be tolerated because not specifically proscribed. Furthermore, provisions declaring "corruption" or "malfeasance" to be grounds for removal could easily be construed in appropriate cases to include unwarranted inaction or improper action. Certainly nothing in the wording of these provisions compels invalidation of replacement statutes, and any ambiguity which may exist should yield to the desirability of upholding a legislative attempt to remedy a serious public problem.

\section{Limitations on Judicial Replacement Power}

Sharp limitations on the procedures for replacing the public prosecutor have resulted from the courts' unwillingness to question the district attorney's decisions. The prosecutor's discretion has been so broadened that his actions are accorded a virtually irrebuttable presumption of propriety. Thus it has been held that a replacement statute may be used only when "circumstances imperatively demand." 45 Other courts have indicated their unwillingness to replace the district attorney by employing strained rationalizations to deny relief. For example, the Tennessee court reversed a trial court order which replaced the

41. Taylor v. State, 49 Fla. 69, 38 So. 380 (1905) ; Territory v. Harding, 6 Mont. 323, 12 Pac. 750 (1887) (dictum); State $e x$ rel. Clyde v. Lauder, 11. N.D. 136, 90 N.W. 564 (1902).

42. Commonwealth v. McHale, $97 \mathrm{~Pa} .397,406$ (1881).

43. State v. Flavin, 35 N.D. $530,541,153$ N.W. 296,300 (1925).

44. For constitutional provisions providing removal for such reasons, see OkLA. Const. art. $\$, \S 1$; N.D. Const. $\$ 196 ;$ W. Va. Const. art. VIII, $\$ 4$.

45. Commonwealth v. Dawson, $3 \mathrm{~Pa}$. Dist. 603 (1894). 
public prosecutor under a provision authorizing removal for inaction, because the lower court based its decision to replace on the prosecutor's "incompetency" rather than on his conceded "failure to prosecute." 46 Use of the replacement power has been somewhat further limited by narrow construction of the authorizing statutes. The courts will not accept a mere probability of inaction or improper conduct, even if the likelihood is extreme ; $;^{47}$ actual failure or refusal to prosecute, or improper action, has invariably been required. In addition, no replacement can be made unless the prosecutor is given notice and an opportunity for hearing. ${ }^{48}$

While narrow construction of replacement statutes may be justifiable, the virtually conclusive presumption of propriety now accorded to the district attorney's decisions should be abandoned. The extent to which district attorneys have abused their discretion demonstrates that this presumption is thoroughly unwarranted. And the availability of a practicable replacement plan makes its continued application unnecessary and undesirable. The success of such a plan depends on the person who fills the void left by the district attorney's inaction.

\section{The Private Prosecutor}

The private prosecutor is a promising candidate for the job the district attorney has left undone. Expansion of the private citizen's role in criminal law enforcement is dictated both by his significant experience in American and foreign criminal law and by the historic policies which have supported his right to participate.

\section{Private Enforcement of Criminal Law}

Despite widespread belief that criminal actions are conducted exclusively by public officials, ${ }^{49}$ private prosecutors in fact play an extensive role in criminal law enforcement. In thirty jurisdictions appellate courts have decided that privately employed attorneys may assist the public prosecutor, ${ }^{50}$ while only

46. Pippin v. State, 34 Tenn. 43 (1854). In some cases a more liberal attitude has been taken by the appellate courts in presuming that the trial court acted properly in appointing a substitute prosecutor. State v. Borgstrom, 69 Minn. 508, 72 N.W. 799 (1897) ; Douglass v. State, 14 Tenn. 525 (1834); Turner v. State, 89 Tenn. 547, 15 S.W. 838 (1891).

47. Commonwealth v. Zerby, $29 \mathrm{~Pa}$. County Ct. 363 (Sch. 1931), held that mere probability that the district attorney would not prosecute because of interest was insufficient to justify his removal.

48. State ex rel. Ilvedson v. District Court, 70 N.D. 17, 291 N.W. 620 (1940).

49. See, e.g., Note, 33 Cornell L.Q. 407, 408 (1948); Report on Prosecution, op. cit. supra note 8 , at 7 .

50. Handley v. State, 214 Ala. 172, 106 So. 692 (1926) ; People v. Powell, 87 Cal. 34s, 25 Pac. 481. (1891); Davis v. People, 77 Colo. 546, 238 Pac. 25 (1925); Oglesby v. State, 83 Fla. 132, 90 So. 825 (1922); Jackson v. State, 156 Ga. 842, 120 S.E. 535 (1923) ; State v. Steers, 12 Idaho 174, 85 Pac. 104 (1906) ; People v. Hayner, 213 Ill. 142, 72 N.E. 792 (1904) ; Williams v. State, 188 Ind. 283, 123 N.E. 209 (1919); State v. Helm, 92 Iowa 540, 61 N.W. 246 (1894) ; State v. Wilson, 24 Kan. 189 (1850) ; Bennyfield v. Commonwealth, 13 Ky. L. Rep. 446, 17 S.W. 271 (1891); State v. Petrich, 122 La. 127, 47 So. 438 
three have said that they may not. ${ }^{51}$ Moreover, sixty-two per cent of 151 public prosecutors from forty-five states who responded to a questionnaire on prosecution procedures stated that they permit privately hired attorneys to assist in criminal proceedings. ${ }^{52}$ Most states find authority for permitting private prosecution in the inherent power of the court to administer justice. ${ }^{53}$ In some jurisdictions the power of the public prosecutor to select assistants is used as the authority for permitting private attorneys to aid in criminal prosecution. ${ }^{54}$ A few states have enacted statutes that give private parties the right to hire assistant prosecutors. ${ }^{50}$ No restrictions have been established on the crimes private attorneys may assist in prosecuting. ${ }^{50}$ The courts have approved of

(1908) ; State v. Bartlett, 105 Me. 212, 74 At1. 18 (1909) ; State v. Rue, 72 Minn. 296, 75 N.W. 235 (1898) ; State v. Mathews, 341 Mo. 1121,111 S.W.2d 62 (1937); State v. O'Brien, 35 Mont. 482, 90 Pac. 514 (1907) ; Polin v. State, 14 Neb. 540, 16 N.W. 898 (1883) ; State v. Hale, 85 N.H. 403,160 Atl. 95 (1932); Gardner v. State, 55 N.J.L. 17, 26 Atl. 30 (Sup. Ct. 1892) ; State v. Lucero, 20 N.M. 55, 146 Pac. 407 (1915) ; State v. Carden, 209 N.C. 404, 183 S.E. 898 (1936) ; State v. Kent, 4 N.D. 577, 62 N.W. 631 (1895) ; Perry v. State, S4 Okla. Crim. 211, 181 P.2d 280 (1947); Commonwealth v. Musto, 348 Pa. 300,35 A.2d 307 (1944) ; Chambers v. State, 22 Tenn. 237 (1842) ; Burkhard v. State, 18 Tex. App. 599 (1885) ; People v. Tidwell, 4 Utah 506, 12 Pac. 61 (1886) ; State v. Ward, 61 Vt. 153, 17 At1. 483 (1888); Jackson v. Commonwealth, 96 Va. 107, 30 S.E. 452 (1898) ; State v. Hoshor, 26 Wash. 643, 67 Pac. 386 (1901) ; State v. Lohm, 97 W. Va. 652, 125 S.E. 758 (1924).

51. Massachusetts, Michigan and Wisconsin have generally refused to permit private attorneys to assist in criminal prosecutions. Commonwealth v. Williams, 56 Mass. 582 (1849) (dictum) ; Meister v. People, 31 Mich. 99 (1875) ; Biemel v. State, 71 Wis. 444, 37 N.W. 244 (1888). However, even in those states there have been exceptions where the private attorney participated in a limited manner or was not hired by interested parties. Commonwealth v. Herman, 253 Mass. 516, 149 N.E. 198 (1925) (no reversible error if a private attorney occupies the district attorney's trial table to confer with the prosecutor); Commonwealth v. Knapp, 27 Mass. (10 Pick.) 477 (1830) (conviction approved since the private assistant, Daniel Webster, was a volunteer and received no compensation from any interested party) ; People v. Schick, 75 Mich. 592, 42 N.W. 1008 (1889) (privately hired attorney permitted to ask a few questions and argue a motion to quash the indictment); People v. Bernis, 51 Mich. 422, 16 N.W. 794 (1883) (Board of County Commissioners permitted to hire a private prosecutor) ; Scheldberger v. State, 204 Wis. 235, 235 N.W. 419 (1931) (investigation and taking statements from witnesses by a private attorney are proper).

52. QuestronnaIre. See note 8 supra.

53. Hayner v. People, 213 I11. 142, 72 N.E. 792 (1904); Williams v. State, 188 Ind. 283, 123 N.E. 209 (1919); Jackson v. Commonwealth, 96 Va. 107, 30 S.E. 452 (1898).

54. State v. Bartlett, 105 Me. 212, 74 Atl. 18 (1909) ; State v. O'Brien, 35 Mont. 482, $90 \mathrm{Pac} .514$ (1907).

55. Under KAN. GEN. STAT. $\$ 19-717$ (1949), counsel hired by the prosecuting witness on any type of action will be recognized as the associate prosecutor. Minnesota and New Jersey statutes authorize any private citizen to hire an attorney to assist the public prosecutor in enforcing election laws. Minn. Stat. Ann. $\$ 211.33$ (West 1947); N.J. Stat. ANA. $\$ 19: 34-63(1940)$. W. VA. CODE ANN. $\$ 404$ (1955) implies that a private citizen has a right to hire an assistant prosecutor.

56. Cases listed in notes 50 supra, 57 infra contain no mention of any crime that a private attorney cannot assist in prosecuting. 
private assistant prosecutors even in actions for such serious crimes as murder, manslaughter, burglary, larceny and rape. ${ }^{57}$

Through his role as assistant prosecutor, the private attorney frequently controls the criminal action. Many states permit privately hired counsel to conduct criminal prosecutions alone with the permission of the public prosecutor and the trial court. .58 While most jurisdictions require that the public prosecutor be present to supervise, no limitation has been imposed on the scope or extent of the private prosecutor's activities. ${ }^{59}$ In response to the questionnaire, many prosecutors stated that they permit private attorneys to control criminal prosecutions. ${ }^{60}$ Unless the privately hired attorney violates the defen-

57. State v. Wilson, 24 Kan. 189 (1880) (murder); Bennyfield v. Commonwealth, 13 Ky. L. Rep. 446, 17 S.W. 271 (1891) (dictum) (manslaughter); State v. Bartlett, 55 Me. 200 (1867) (larceny) ; State v. Tough, 12 N.D. 425, 96 N.W. 1025 (1903) (burglary); State v. Lohm, 97 W. Va. 652, 125 S.E. 758 (1924) (rape). Private attorneys have also assisted in prosecuting many other crimes. Jackson v. Commonwealth, $96 \mathrm{Va} .107,30$ S.E. 452 (1898) (felonious wounding) ; State v. Ward, 61 Vt. 153, 17 Atl. 483 (1888) (arson) ; Perry v. State, 84 Okla. Crim. 211, 181 P.2d 280 (1924) (adultery); Commonwealth v. Derr, $39 \mathrm{~Pa}$. County Ct. 125 (Berks 1947) (fornication); State v. Hoshor, 26 Wash. 643, 67 Pac. 386 (1901) (embezzlement) ; Williams v. State, 1SS Ind. 283, 123 N.E. 209 (1919) (bribery) ; People v. Calkins, 8 Cal. App. 2d 251, 47 P.2d 544 (1935) (criminal libel); LaShar v. People, 74 Colo. 503, 223 Pac. 59 (1924) (obtaining money under false pretenses); Bergstrasser v. People, 134 IIl. App. 609 (1907) (gambling); State v. O'Brien, 35 Mont. 482, 90 Pac. 514 (1907) (illegal liquor sales).

58. People v. Powell, 87 Cal. 348, 25 Pac. 481 (1891) ; State v. Bartlett, 105 Me. 212, 74 At1. 18 (1909) ; State v. Rue, 72 Minn. 296, 75 N.W. 235 (1898) ; State v. Ward, 61 Vt. 153, 17 At1. 483 (1888). In Jackson v. Commonwealth, 96 Va. 107, 30 S.E. 326 (1898), and State v. Stafford, 89 W. Va. 301, 109 S.E. 326 (1921), private attorneys gained sole control of the prosecution after starting as the public official's assistant.

There is some indication that private prosecution has become quite common in some areas without attracting widespread attention. In approving a privately conducted prosecution for fornication, the court of Berks County, Pennsylvania said it was a common practice for such actions to be privately prosecuted. Commonwealth v. Derr, supra note 57. In Lanni v. Bayonne, 7 N.J. Super. 169, 72 A.2d 397 (App. Ct. 1950), the propriety of private criminal prosecution to enforce a municipal zoning ordinance was uncontested.

59. Oglesby v. State, 83 Fla. 132, 90 So. 825 (1922); Hayner v. People, 213 Ill. 142, 72 N.E. 792 (1904); State v. Wilson, 24 Kan. 189 (1880); Perry v. State, 84 Okia. Crim. 211, 181 P.2d 280 (1947) ; State v. Kent, 4 N.D. 577, 62 N.W. 631 (1895); Burlhard v. State, 18 Tex. App. 599 (1855). Aside from the requirement that a member of the public prosecutor's staff be present at the trial, no limitations were imposed on private prosecutors in cases cited in notes 50,57 supra.

The Louisiana Supreme Court held that if the district attorney is present, he can entrust the conduct of the trial exclusively to the private prosecutor. State v. Petrich, 122 La. 127, 47 So. 438 (1908). Other courts have approved unlimited activity for private prosecutors as long as the public official is in charge. Thalheim v. State, 38 Fla. 169, 20 So. 938 (1896) ; Jackson v. State, 156 Ga. 842, 120 S.E. 535 (1923) ; State v. Matthews, 341 Mo. 1121, 111 S.W.2d 62 (1937).

60. QuestionnaIRE. See note 8 supra. Sixty per cent of the responding prosecutors stated that they permit privately hired attorneys to aid in the presentation of the case at trial with no restriction on the scope of his activity. The private prosecutor is permitted to control the criminal action of $16 \%$ of the responding public officials with the sole limita- 
dant's right to a fair trial by using unfair tactics, appellate courts will not ordinarily reverse a successful private prosecution. ${ }^{61}$ However, some courts will reverse a conviction if the relationship between the accused and private prosecutor or hiring citizen might have produced unfairness. ${ }^{62}$

Private prosecution is especially common before magistrates, municipal courts and justices of the peace. ${ }^{63}$ Questionnaire responses disclosed that in at least twenty-eight states, it is a common practice for private attorneys to prosecute criminal actions in the lesser courts. ${ }^{64}$ Since these courts customarily have jurisdiction over all misdemeanors, ${ }^{05}$ private citizens may initiate criminal actions which result in jail terms up to one year. In many states the latitude of private prosecutors is extended by the fact that the public prosecutor need not attend such courts unless the presiding official requests his appearance. ${ }^{66}$ If the district attorney chooses, he can control the proceedings in these courts ; ${ }^{67}$ in his absence, a private attorney is in complete charge of the prosecution. ${ }^{\text {ss }}$

tion that a member of the prosecutor's staff be present at the trial. Three per cent of the public prosecutors would give private attorneys complete control of the criminal action.

61. Davis v. People, 77 Colo. 546, 238 Pac. 25 (1925) ; Hayner v. People, 213 I11. 142, 72 N.E. 792 (1904) (dictum) ; Commonwealth v. Musto, 348 Pa. 300, 35 A.2d 72 (1944).

62. State v. Halstead, 73 Iowa 376,35 N.W. 457 (1887) (after ceasing to represent the defendant, an attorney cannot join the prosecution) ; State v. Scott, 72 Idaho 202, 239 P.2d 258 (1951) (private prosecutor cannot be interested in a civil case involving the same set of facts) ; Flege v. State, 93 Neb. 610, 142 N.W. 276 (1913) (reversible error for a party once a suspect of committing the crime in question to hire an assistant prosecutor); Compton v. Commonwealth, 163 Va. 999, 175 S.E. 879 (1934) (public officials connected with trial administration cannot employ a private attorney to assist in the prosecution). See also State v. Lohm, 97 W. Va. 652, 125 S.E. 758 (1924) (private prosecutor must reveal the identity of his employer). Contra, State v. Carden, 209 N.C. 404, 183 S.E. 898 (1936). Appearance of the private prosecutor before the grand jury, and a great disparity in number and experience between prosecution and defense counsel, have also led to reversal of a conviction. Cobletz v. State, 164 Md. 558, 166 Atl. 45 (1933) ; People v. Blevins, 251 I11. 381,96 N.E. 214 (1911).

Employment of the private prosecutor on a contingent fee is another possible motivation for unfairness. State v. Hoshor, 26 Wash. 643, 67 Pac. 386 (1901), affirmed an embezzlement conviction when the private prosecutor was hired on a contingent fee; however, a private prosecutor's employment contract based on a contingent fee will not be enforced. Price v. Caperton, 62 Ky. (1 Duv.) 207 (1864); Baca v. Padilla, 26 N.M. 223, 190 Pac. 730 (1920).

63. These courts act in a dual capacity as committing magistrates in felony cases and as trial courts for misdemeanors. Miller, Compromise of Criminal Cases, 1 So. CaLIF. L. REv. 1,8 (1927).

64. Questionnaire. See note 8 sipra.

65. See, c.g., Fla. Stat. Ann. \$ 37.01 (2) (1943) ; Idamo Code Ann. \$ 1-1406 (1948); UTAH CODE ANN. § 78-5-4 (1953).

66. See, e.g., Idaho Code Ann. \$ 31-2604(2) (1948); Kan. Gen. Stat. \$ 19-703 (1949); Orla. Stat. Ann. tit. 19, § 184 (1937).

67. State v. Court, $123 \mathrm{Kan} .774,256$ Pac. 804 (1927) ; State ex rel. Muller v. Judge, 106 La. 437, 31 So. 50 (1901) ; Ore. Rev. Stat. \$ 156.520 (1953).

68. QuestionnaIRE. See note $\&$ supra. Responses by district attorneys listed a wide range of offenses commonly prosecuted. The public officials suggested no limitation on the offenses private parties could prosecute in the lesser courts. 
Some states fortify private prosecution in these courts by statutes which prohibit exclusion by a public prosecutor of assisting private attorneys. ${ }^{60}$

Somewhat different, related forms of private prosecution which are extensively used are qui tam actions and multiple damage suits. ${ }^{70}$ Twenty-one states and the federal government have qui tam statutes which provide that private citizens can receive part of the fine for successfully prosecuting a wide variety of crimes such as violations of tax, gambling, narcotics and liquor control laws. ${ }^{71}$ Frequently referred to as a type of qui tam action, multiple damage suits are a hybrid action combining the remedial element of a civil suit with the penal aspect of a criminal prosecution. ${ }^{72}$ Multiple damage actions differ from tradi-

Allowing private citizens to prosecute minor offenses is sometimes justified as a means to keep the public prosecutor free for more important matters. This rationale led Wiscon$\sin$ to relieve the district attorney of the duty to prosecute certain minor offenses. WIs. STAT. $\$ 59.44$ (1953). See note 3 supra. While originally conceived as a means of allowing private parties to act on minor offenses, this provision was used for the prosecution of a very serious case of assault and battery in Bartell v. State, 106 Wis. 342, 82 N.W. 142 (1900). The Wisconsin legislature refused to limit this statute in 1951, and recommendations have since been made that it be broadened to allow private citizens to take over the district attorney's duties on other minor crimes. Note, 1953 WIS. L. Rev. 170. For an account of private prosecution by Connecticut grand jurors, see Pickett, The Office of the Public Prosecutor in Connecticut, 17 J. CRm. L. \& Crinrnologx 348, 351 (1927).

69. N.Y. Code CrIMr. Proc. $\$ 203$; and Ore. Rev. Stat. $\$ 133.760$ (1953) give the private complainant the right to hire counsel and be present at all proceedings before the magistrate. See People ex rel. Pringle v. Conway, 121 Misc. 620, 202 N.Y. Supp. 104 (Sup. Ct. 1923). People ex rel. Howes v. Grady, 66 Hun. 465, 21 N.Y. Supp. 381 (N.Y. Sup. Ct. 1892), aff'd, 144 N.Y. 685,39 N.E. 858 (1895), held that in the absence of the district attorney and his assistants, private counsel may appear and conduct the prosecution alone in the magistrate's courts.

70. Qui tam or informer actions originated in the middle ages and were extensively used in Tudor England. The primitive state gave private citizens a personal pecuniary interest in order to extend the long arm of criminal law enforcement. 4 HoLdsworrH, $A$ History of the English LAw 355 (1924). See text at note 96 infra for discussion of the development of multiple damage actions.

71. See, e.g., 12 Stat. 698 (1863), as amended, 31 U.S.C. $\$ \$ 231-32$ (1952) (fraud in government contracts) ; 38 STat. 277 (1914), 21 U.S.C. $\$ 183$ (1952) (narcotics violations); 18 U.S.C. $\$ 3113$ (1952) (transporting liquor into Indian territory) ; GA. Cone ANN. \$922103 (1937) (tax frauds) ; Ky. REv. STAT. ANN. \$372.040 (Baldwin 1955) (gambling); Idaho Code Ann. \$25-2109 (1948) (stallions and mules running loose) ; PA. STAt. ANn. tit. $18, \$ 3222$ (Purdon 1945) (shooting pigeons in Philadelphia). For the application of qui tan statutes, see State v. Fillyan, 3 Ala. 735 (1842) (action to collect part of the penalty for illegal billiard table operation) ; Payne v. Coursey, $20 \mathrm{Ga} .585$ (1856) (tax evasion); Indianapolis \& St. L. Ry. v. People, 91 I11. 452 (1879) (failure to bring trains to a stop at intersecting railroad lines); Yocum v. Daniel, $24 \mathrm{Ky} .14$ (1829) (action to collect part of the penalty for dueling); Martin v. M'Night, 1 Tenn. 330 (1808) (peddling without a license). Most jurisdictions hold that the informer can initiate the prosecution without waiting for action by the public prosecutor. Adams v. Wood, 6 U.S. (2 Cranch) 336 (1805) ; Canfield v. Mitchell, 43 Conn. 169 (1875) ; State ex rel. Kemp v. Hannibal \& St. J. Ry., 30 Mo. App. 494 (1888). Contra, Smith v. Looks, 108 Miass. 139 (1871).

72. Historically $q u i$ tam actions involved a suit for the state as well as for the private prosecutor. 4 HoLDswort $o p$. cit. supra note 70 , at 355 . More recently, actions have been 
tional qui tam suits in that the entire recovery is retained by the prosecutor. While qui tam type laws were designed for use before the advent of modern law enforcement techniques, they are still applied. As recently as 1943 the United States Supreme Court affirmed a judgment giving a private citizen onehalf of a $\$ 315,000$ fine imposed in a prosecution which he had conducted under a federal qui tam statute. ${ }^{73}$

Persuasive foreign precedents offer support for private prosecution. In England private prosecution is the basic system of criminal law enforcement. ${ }^{74}$ Private citizens and policemen acting as private citizens initiate the vast majority of all prosecutions. ${ }^{75}$ A state agency, the Office of the Director of Public Prosecutions, conducts the remaining actions, most of which are the more serious offenses. ${ }^{76}$ While most criminal actions are conducted by the public

labeled "qui tam" and "penal" even though the private prosecutor keeps the entire multiple damage judgment. Marvin v. Trout, 199 U.S. 212 (1905) ; Lambur v. Yates, 148 F.2d 137 (Sth Cir. 1945) ; Jacob v. Clark, $115 \mathrm{Ky} .255,72$ S.W. 1095 (1903). Multiple damage suits are characteristically labeled "civil" suits. E.g., Bluefields S.S. Co. v. United Fruit Co., 243 Fed. 1 (3d Cir. 1917).

Constitutions and many statutes-statutes of limitations, for example-require classifying these statutes as "civil" or "penal." The inadequacy of this traditional dichatomy is dramatized by the fact that the same law has been classified as penal by the Kentucky Court of Appeals and as remedial by the United States District Court for Kentucky. Jacob v. Clark, supra; Salonen v. Farley, 82 F. Supp. 25 (E.D. Ky. 1949). The statute involved in these cases was Ky. Rev. Stat. ANn. $\$ 372.040$ (Baldwin 1955), which provides that anyone may recover from a gambler treble the amount of his gambling winnings. For discussion of the difficulty in categorizing these statutes as either civil or penal, see Wilson, Origin and Limited Life of the Anti-trust Cause of Action, 21 Kan. CITY L. Rev. 127 (1953).

73. United States ox rel. Marcus v. Hess, 317 U.S. 537 (1943), applying the Act of March 2, 1863, c. 67, $\$ 6,12$ STAT. 698. Congress has since amended this statute to provide that notice of such suits must first be given to the United States attorney, and that a private party may then bring the action only if the government fails to act within sixty days after being notified or fails to prosecute diligently for six months after commencing the action. Even if a private citizen conducts a successful prosecution, he will be awarded only what the trial court considers appropriate, not to exceed one-fourth of the total fine. 57 Stat. 608 (1943), 31 U.S.C. $\$ \$ 231-32$ (1952). For relatively recent qui tam actions, see People $c x$ rel. Wegner v. Columbia Nat'l Life Ins. Co., 87 Ill. App. 37 (1914) ; cases cited in note 72 supra.

As law enforcement methods have become more efficient, qui tam actions have been discouraged. Maryland has repealed all its qui tam statutes. Mo. ANn. CODE Gen. Laws art. 38, $\$ 3$ (1951). The Michigan Supreme Court has long considered qui tam prosecutions as disfavored actions. Meister v. People, 31 Mich. 99 (1875). Even some advocates of qui tam legislation defend it only as a means of setting one rogue to catch another. See remarks of Senator Howard quoted in United States ex rel. Bayarsky v. Brooks, 154 F.2d 344, 345-46 (3d Cir. 1946).

74. Jackson, The Machinery of Criminal Justice in England 108-10 (1953); Atkinson, The Department of the Director of Public Prosecutions, 22 CAN. B. REv. 413 (1944); Mathew, The Office and Duties of the Director of Public Prosecutions 4 (1950).

75. Id. at 4; JACKson, op. cit. supra note 74, at 108-10.

76. Id. at 108; Atkinson, supra note 74, at 415 . 
prosecutor in Scotland, private prosecution may be authorized by the court if the public official fails to act. ${ }^{77}$ France and Austria have also used private prosecution to restrain the discretion of the public prosecutor. ${ }^{78}$ Citizens may privately prosecute minor crimes in France. ${ }^{79}$ Spain and Pakistan permit private prosecution of certain crimes. ${ }^{30}$ In Germany private citizens may prosecute many crimes including libel, slander, assault with a deadly weapon, vandalism and unfair competition. ${ }^{81}$ In China, settlement of criminal disputes has traditionally been left primarily in private hands. ${ }^{82}$ Although reform movements and extensive code revisions have occurred in some of these countries, private prosecution laws have emerged intact and have, indeed, drawn no significant criticism. ${ }^{83}$

\section{Private Rights to Enforce the Criminal Law}

Every citizen has, in a sense, a right to the efficient performance of all governmental functions, but only in the field of criminal law enforcement does this right entitle him personally to assume a task which has been performed inadequately. ${ }^{84}$ The primary policy justification for this unique exception is that it promotes society's interest in better and more efficient law enforce-

77. Private criminal action is commonly conducted in Scotland with the approval of the public prosecutor; however, if the public official refuses to proceed or allow private action, the High Court of Justiciary may authorize justifiable criminal prosecutions. J. \& P. Coates Ltd. v. Brown, [1909] Sess. Cas. 29 (Scot. Justiciary Ct.) ; Normand, The Public Prosecutor In Scotland, 54 L.Q. Rev. 345, 347-48 (1938).

78. France uses private prosecution to make up for neglect, inertia or possible corruption inherent in public prosecution. Wright, French Criminal Procedure, 44 L.Q. Rev. $324,329-30$ (1928). Austria has permitted the injured party to replace the public prosecutor with a private attorney in case of abandonment of the action by the public official. Esmein, A History of Continental Crinimal Procedure 597 (1913).

79. Donnedieu de Vabres, Tratté Elémentaire de Droit Crinnnel 635 (1944).

80. For information on private prosecution in Spain, see Essrens, op. cit. supra note 78, at 596-97. In a lecture at the Yale Law School on December 2, 1954, Zafrulla Kahn, formerly Foreign Minister of Pakistan, stated that noncognizable or minor crimes are privately prosecuted in Pakistan.

81. Arts. 376-77 StRAFPROZEBORDNUNG (1943).

82. Hsien Chin Hu, Common Descent Group in China and its Functions 5354 (1948).

83. English criminal procedure has been substantially revised in recent years; however, private prosecution has been retained and praised. The Director of Public Prosecutions is among those urging that private citizens should keep their broad power to conduct criminal actions. Mathew, op. cit. supra note 74, at 12-16. In 1953 the German Criminal Code and the Code of Criminal Procedure were substantially revised, but private prosecution-was retained. Drittes Strafrechtsänderungsgesetz of Aug. 6, 1953, [1953] BundesGesetzBLATT pt. 1, at 743 (German Federal Republic). On French private prosecution see Jacobson in Revue Politique et Parlementaire, Oct. 10, 1922.

84. The people do not abdicate their right to competent law enforcement by selecting a public prosecutor. See Taylor v. State, 49 Fla. 69, 38 So. 380 (1905) ; Tull v. State, 99 Ind. 238 (1884); Territory v. Harding, 6 Mont. 323, 12 Pac. 750 (1887). 
ment. ${ }^{85}$ The magnitude of the task of law enforcement has necessitated the assistance of private citizens from Elizabethan days, when the informer was first utilized, to the present, when the citizen witnessing a crime has the power to arrest. ${ }^{s 6}$ The private citizen's peculiar knowledge of the facts plus his interest in diligent prosecution have further commended him as a proper person to aid in law enforcement.

While allowance of private participation is usually explained solely in terms of the value to society of the increased law enforcement thereby obtained, ${ }^{87}$ an examination of the history and practice of criminal law demonstrates that a policy of encouraging vindication of purely personal grievances has played a significant part. The early common law permitted the injured party to prosecute criminally as a substitute for private vengeance. ${ }^{88}$ And private prosecution, retained by England today, has been characterized as a procedure for the vindication of private as well as public rights. ${ }^{89}$ In the United States a prominent example of the policy of encouraging vindication of personal grievances through the criminal law is found in the recognition given the private assistant prosecutor. Since he often appears in situations where the adequacy of public prosecution has not been questioned, his presence can be attributed only to a recognition by the law that the individual should be allowed to seek personal satisfaction.90 Where assistant private prosecutors are authorized by statute, there is further recognition of a purely personal interest in enforcement.91 By

85. See, $e .7$., Thalheim v. State, 38 Fla. 169, 20 So. 938 (1896) ; Bennyfield v. Commonwealth, 13 Ky. L. Rep. 446, 17 S.W. 271 (1891) ; State v. Kent, 4 N.D. 577, 62 N.W. 631 (1895).

86. See note 70 supra; Vaccaro v. Collier, 3S F.2d 862 (D. Md. 1930).

87. According to classical doctrine, criminal law remedies only offenses against society, and civil recovery is the measure of the individual's rights. Hall, General PRINCIPLES or Criminal Law 191-96 (1947) ; Mrller, Criminal Law 20-22 (1934); Prosser, Torts 7-8 (2d ed. 1955).

88. Moley, Politics and Criminal Prosecution 193 (1929). See also Wright, supra note 78 , at 329 .

89. 1 Stephen, A History of the Criminal Law in England 496 (1883). See also MATHEW, op. cit. supra note 74, at 4.

90. See Oglesby v. State, 83 Fla. 132, 90 So. 825 (1922); State v. O'Brien, 35 Mont. 482, 90 Pac. 514 (1907); State v. Lohm, 97 W. Va. 652, 125 S.E. 758 (1924) (dictum).

91. Kan. Gen. Stat. \$19-717 (1949); Minn. Stat. Ann. \$211.33 (West 1947); and N.J. Stat. ANn. § 19:34-63 (1940) provide that private citizens may hire assistant prosecutors. In addition Kan. GEN. STAT. $\$$ 19-718, 19-719 (1949) provides that an assistant prosecuting attorney may be appointed at the county's expense upon a petition by the prosecuting witness in counties of less than 10,000 people.

Further recognition of private rights to enforce the criminal law is indicated by several adultery statutes which provide that only the injured spouse may initiate adultery prosecutions. Ariz. Code Ann. § 43-401 (1939); Iowa Code ANn. § 702.1 (1950) ; Mice. Stat. AnN. § 28.220 (1938); MinN. Stat. AnN. \& 617.15 (West 1947) ; N.D. Rev. Code § 122210 (1943) ; Wash. Rev. Code Ann. $\$ 9.79 .110$ (1951). OkLa. Stat. Ann. tit. 21 , $\$ 871$ (1937) allows any citizen to register a criminal complaint if adultery is "open and notorious." Short of that, only the wronged spouse can start an adultery prosecution. Michigan and Olilahoma, on adultery which is not "open and notorious," strengthen private control by 
permitting the private assistant to challenge the district attorney's decision to dismiss a prosecution, some of these statutes give a private citizen a right to plead for vindication of his personal interest in conviction after the public prosecutor has determined that society's interests require no further action. Three states allow the private attorney to force a full hearing of the district attorney's decision to dismiss, with final determination reserved for the court. ${ }^{92}$ An analogous statutory provision specifies that no accused party may be discharged without notice to all interested parties and an opportunity to contest his release. ${ }^{93}$

Multiple and punitive damage actions are further evidence of approval by the law of personal satisfaction through enforcement of criminal-type sanctions. Multiple damage actions originated in Roman law, where the culprit was required to pay the victim double or treble damages for criminal acts. ${ }^{9.1}$ In fifteenth century England, when there was no clear distinction between civil and criminal offenses, an action of debt for two or three times the damage suffered was a common remedy for wrongs now considered criminal. ${ }^{95}$ Nultiple damage actions for offenses within the periphery of the criminal law have endured to the present. ${ }^{96}$ And in contemporary damage law, there is often a correlation between the amount recovered and the antisocial nature of the act. ${ }^{07} \mathrm{Thus}$, in

requiring that the prosecution be discontinued at the request of the initiating spouse. People v. Dalrymple, 55 Mich. 519,22 N.W. 20 (18\$5) ; Taylor v. State, 29 Ok:la. Crim. 160, 232 Pac. 963 (1925). While these unique adultery laws may be explained as devices to keep the home intact if the wronged spouse is willing to condone the act, there are substantial indications that these statutes are a recognition of private rights. Reversing an adultery conviction, the court in State v. La Bounty, 64 Wash. 415, 116 Pac. 1073 (1911), said that adultery was a crime against husband or wife personally, rather than an offense against society. Adultery is referred to as a "private wrong" in Lee v. State, 28 Okla. Crim. 397, 402, 231 Pac. 324 (1924).

92. Kan. Gen. Stat. \$19-717 (1949) ; Mrnw. Stat. Ann. \$211.33 (West 1947) ; N.J. Stat. ANn. \$ $19: 34-63(1940)$.

93. ORE. Rev. Stat. $\$ 34.650$ (1953). The Cleveland Foundation Survey made an analogous recommendation that no nolle prosequi should be granted until ample opportunity was given for complaining witnesses and police officers to contest that action. CIEvEland Foundation Survey, Criminal Justice In Cleveland 328 (1922).

94. 1. STEPHEN, op. cit. supra note 89, at 9-10.

95. 2 Holdsworth, A History of Eivglish LAw 453 (1924).

96. Section 4 of the Clayton Act gives treble damages to anyone injured as a result of violation of the antitrust laws. 38 STAT. 731 (1914), as amended, 15 U.S.C. $\$ 15$ (1952). Federal price control regulations give injured parties an action for treble damages. 64 STAT. 811 (1950), 50 U.S.C. $\$ 2109$ (c) (1952). Violation of federal overtime wage rates entitles the injured employee to double damages. 52 Stat. 1069 (1938), as amended, 29 U.S.C. $\S 216$ (b) (1952).

The vague line separating civil and criminal actions is demonstrated in the multiple damages area. See note 72 supra.

97. The courts have held that punitive damages are penal in nature and are imposed when an unlawful act is committed with criminal indifference or malice. E.g., Philadelphia, W. \& B. Ry. v. Quigley, 62 U.S. (21 How.) 208 (1858) ; Cashin v. Northern Pac. Ky., 96 Mont. 92, 28 P.2d 862 (1934) ; Voltz v. General Motors Acceptance Corp., 332 Pa. 141, 2 A.2d 697 (1938). Like criminal sanctions, punitive damages are imposed to punish the 
tort law the same injury may entitle the harmed party to nothing if caused without fault, to single damages if produced negligently, or to punitive damages if intentionally inflicted. ${ }^{98}$ Since civil satisfaction requires only that the injured party be made whole, recovery in excess of compensatory damages indicates punishment for a criminal-type act. ${ }^{99}$ Neither promotion of law enforcement nor deterrence explains the existence of multiple or punitive damages in all cases. For example, punitive tort damages are allowed in situations where compensation amply stimulates litigation to enforce society's norms. ${ }^{100}$ And the objective of deterrence is furthered only by the imposition of extra damages; it is not advanced by the fact that the injured party receives them rather than the state. Thus, the right of the injured individual rather than society to bring the suit and receive the excess over compensation indicates that he has a personal right to extract a punishment from the wrongdoer.

$\Lambda$ system of private prosecution can be justified in terms of both society's interest in increased law enforcement and the individual's interest in vindication of personal grievances. Full participation by the citizen as a private prosecutor is needed to cope with the serious threat to society posed by the district attorney's improper action and inaction. This rationale alone is adequate to support private prosecution. To the extent that this plan affords an opportunity to satisfy personal grievances, it further commends itself as a recognition of very real and defensible human motives. Holmes suggested that vengeance is a justifiable objective of the criminal law. ${ }^{101}$ He quotes with approval Stephen's statement that "the criminal law stands to the passion of revenge in much the same relation as marriage to the sexual appetite."102 A leader in ethical jurisprudence,

wrongdoer and as a deterrent to others in society's interest. E.g., Eshelman v. Rawalt, 298 III. 192, 131 N.E. 675 (1921) ; Martin v. Cambas, 134 Ore. 257, 293 Pac. 601 (1930) ; Foster v. Bourgeois, 253 S.W. 880 (Tex. Civ. App. 1923). The analogy between crimes and torts which warrant punitive damages is further supported by the requirement of evil or malicious intent in both. E.g., Fidelity Appraisal Co. v. Federal Appraisal Co., 217 Cal. 307, 18 P.2d 950 (1933) ; Martin v. Cambas, 134 Ore. 257, 293 Pac. 601 (1930); Step v. Black, 14 Tenn. App. 153 (1931) (dictum). Criminal sanctions and punitive damages are so similar that the Indiana Appellate Court refused to allow punitive damages where the defendant would also be liable criminally because of his right not to be punished twice for the same offense. Skufakiss v. Duray, 85 Ind. App. 426, 154 N.E. 289 (1926).

Commentators have agreed that punitive damage actions are penal in nature and reflect treatment customarily afforded criminal acts. Hali, General Principles of Criminal Law 212-13 (1947); Willis, Lleasure of Damages When Property Is Wrongfully Taken by a Private Indizidual, 22 Hanv. L. Rev. 419, 420-21 (1909); Demogue, Validity of the Theory of Compensatory Damages, 27 YaLE L.J. 585, 592 (1918).

98. Prosser, Torts 5-6, 9-11, 165-66 (2d ed. 1955).

99. Willis. supra note 97 , at 422 .

100. Grinnel, Traffic Jam in the Courts, 39 Mass. L.Q. 6 (1954); Doyle, Traffic Jam in the Courts from the Point of Vieze of the Insurance Industry, 39 Mass. L.Q. 9 (1954); Virtue, What Is the Log Jam Problem?, 15 F.R.D. 207, 214 (1954).

101. Holares, The Common Law $39-42$ (1881.). See also Hall, op. cit. supra note 97 , at 202.

102. HoLMEs, op. cit. supra note 101 , at $39-42$. 
Morris Cohen commented that the law should provide avenues of satisfaction for vengeance and retribution, which are deeply grounded in human nature. ${ }^{102}$ Cohen said that it was "sentimental foolishness" to disregard the prevalent retribution motive which prevails in relations between men and nations. ${ }^{104}$ Both Holmes and Cohen stressed the importance of accommodating such desires within the law rather than forcing them to be satisfied outside it. ${ }^{105}$ Moreover, a degree of privity of interest exists between the harmed party and the exacting of justice. The injured individual was most severely harmed by the criminal act; he will be uniquely affected by the failure of society to prosecute. ${ }^{100}$ Furthermore, the injured individual's grievances cannot be satisfied by civil remedies if the district attorney refuses to prosecute his malefactor. Crimes against the person cannot be adequately measured or remedied by monetary damages. ${ }^{107}$ In addition, the criminal is almost always judgment-proof. ${ }^{108}$ Thus, if the public prosecutor refuses to act, the injured individual is likely to have no recourse against his malefactor unless he is allowed to invoke criminal sanctions in his own right.

Allowing satisfaction of private grievances through private participation in the criminal law is not, of course, unqualifiedly beneficial. For such a policy is subject a fortiori to the principal criticism currently made of the public prosecutor's adversary role in criminal law: that private rights are often lost and the truth obscured in an overzealous struggle for conviction. And indeed, it seems likely that the unfriendly attitude of the courts toward private prosecution is traceable in some measure to a distaste for the introduction of an element of private vengeance into criminal law administration. ${ }^{109}$ However, as has been seen, release of private vengeance through the criminal law is a historic policy which retains some validity today. And experience has demonstrated that the private prosecutor plays as fairly as his public counterpart.110

103. Cohen, Moral Principles of the Criminal Law, 49 YALE L.J. 987, 1010-12 (1940).

104. Id. at 1011.

105. Holdres, op. cit. sutpra note 101, at 41-42; Cohen, supra note 103, at 1011-12.

106. See Baker \& De Long, The Prosecuting Attomey: The Process of Prosecution, 26 J. Crin. L. \& Criminology 185, 197 (1935).

107. Holmes, op. cit. supra note 101 , at 40.

108. Inability to pay damages may, in itself, justify the imposition of criminal sanctions. For example, when MacAuley drafted the India Penal Code, he made breach of contract for carrying passengers a crime. Since Palanquin bearers were too poor to pay damages and women and children had to be carried out of desolate tracts, a criminal sanction was the only means available to induce the bearers to fulfill their contracts. HoLsies, op. cit. supra note 101 , at $40-41$.

109. See Oglesby v. State, 83 Fla. 132, 90 So. 825 (1922) ; Meister v. People, 31 Mich. 99 (1875); Biemel v. State, 71 Wis. 444, 37 N.W. 244 (1888).

110. Cases cited in notes 50,57 supra indicate that the private prosecutor's behavior is seldom criticized. A possible explanation for the dearth of objections to the private prosecutor's tactics is that he is held only to the standards of the public prosecutor. The public prosecutor is recognized as an advocate. Di Carlo v. United States, 6 F.2d 364 (2d Cir. 1925) ; Ex parte Hayter, 16 Cal. App. 211, 116 Pac. 370 (1911) ; Keyes v. State, 122 Ind. 527, 23 N.E. 1097 (1890). Moreover, the public prosecutor has been known to use un- 
Certainly, vengeance is not necessarily a more corrupting motive than political ambition. Furthermore, judicial controls are available to minimize abuses where danger exists, and would undoubtedly be more carefully exercised in private than in public prosecutions. ${ }^{111}$ It seems likely, in sum, that the few abuses which might evade controls, in a system of private prosecution of limited scope, would constitute far less of an evil than the threat to society currently posed by the district attorney's stranglehold on prosecuting machinery.

\section{A Practical Plan}

An alliance of private advocacy with the judicial replacement power would minimize deficiencies in criminal law enforcement. A system of private prosecution, under which the court could substitute a petitioning citizen's counsel for an errant public prosecutor, can be both effective and practicable. And this system can be constructed so that neither the rights of the accused, nor the primary responsibility of the public prosecutor for conducting criminal prosecutions, will be impaired.

\section{Effectiveness of Private Prosecutor and Trial Judge}

The private attorney will remedy the failure of the district attorney more effectively than a substitute public official. Opportunity for private prosecution will provide aggrieved individuals with incentive to challenge the prosecutor's conduct. Having witnessed the abuse of discretion by one public official, the person concerned about violations of law might be reluctant to take action which would result only in substitution of one official for another. Where the refusal of the first prosecutor to act was motivated by economic or political pressure, the private citizen's preference for private action would seem especially justified. ${ }^{112}$ And if private citizens are given incentive to convince a court that the prosecutor's discretion has been abused, the courts will thereby acquire the information necessary for effective use of the judicial replacement power. ${ }^{113}$

Moreover, criminal prosecution would benefit from the continuity provided by having the private complainant follow up his objections to the public prosecutor's conduct by prosecuting the criminal action himself. The case against the defendant must be organized with some care for the purpose of demonstrating that the district attorney has abused his discretion. Duplication of effort will

fair tactics. People v. Creasy, 236 N.Y. 205, 140 N.E. 563 (1923) (use of false testimony); Venable v. State, 84 Tex. Crim. 354, 207 S.W. 520 (1918) (use of threats and coercion); State v. Russell, 83 Wis. 330, 53 N.W. 441 (1892) (ruse to get testimony). For additional unfair tactics used by public prosecutors, see Notes, 24 MICH. L. Rev. 834 (1926), 4 B.U.L. REv. 139 (1924).

111. The courts insist that the trial court can insure that the defendant receives a fair trial despite the participation of private prosecutors. Hayner v. People, 213 I11. 142, 72 N.E. 792 (1904) (dictum) ; State v. Wilson, 24 Kan. 189 (1880) ; State v. Bartlett, 55 Me. 200 (1867).

112. See notes 7, 16, 20 supra.

113. See note 28 supra. 
thus be avoided by allowing the private attorney then to act as the prosecutor rather than to bring in a substitute public official. Finally, the private prosecutor would be likely to conduct a vigorous prosecution. ${ }^{114}$

There is considerable evidence that private citizens are ready to take the initiative if given a method of combating laxity in law enforcement. The Kefauver Committee reported several situations where private citizens were interested in initiating indictments but were stymied by the district attorney's refusal to prosecute. ${ }^{115}$ Furthermore, the extensive participation of privately hired assistant prosecutors in the United States, and private prosecutors in England, demonstrates the willingness of the citizen to take action if permitted to do so. 116

The trial court can effectively fill this role of exercising the discretion necessary to prevent undesirable prosecutions. Decisions involving competing demands for leniency, deterrence and protection of society's interests are not novel for judges. ${ }^{117}$ The court is even better qualified than the public prosecutor to evaluate the availability of time on the court calendar. The adequacy of judicial discretion as a basis for initiating private prosecutions is demonstrated by the satisfactory operation of private prosecution in England. ${ }^{118}$ This experience further attests to the sufficiency of court approval as a safeguard against unfounded and malicious actions. ${ }^{119}$

114. Some have supported private prosecution on the ground that it would insure a vigorous presentation of the state's case. Keyes v. State, 122 Ind. 527, 23 N.E. 1097 (1890); People v. Tidwell, 4 Utah 506, 12 Pac. 61 (1886); Note, 5 Wrs. L. Rev. 97 (1929). For authorities taking a contrary view of the desirability of a partisan approach in criminal law administration, see note 109 supra.

115. Private citizens of Miami and Hollyw̧ood, Florida, Covington, Kentucky, Harrison County, Mississippi, and the New Orleans area made extensive and futile efforts to initiate criminal prosecutions. Kefauver Committee Interim Report 10; Kefauver Committee Third Interim Report 83-84; Kefauver Committee Final Report 43-44, 73, 75.

Although the Kefauver Committee did not recommend private prosecution, its reports repeatedly emphasized the need for action by private citizens to combat widespread crime. Kefanver Committee Third Interim Report 30; Kefanver Committee Final Report 2, 6, 12.

116. The frequency of use of private assistant prosecutors is demonstrated by the large percentage of public prosecutors who stated, in response to the questionnaire, that they have permitted privately hired attorneys to assist in criminal prosecutions. See note $\mathbf{5 2}$ supra. The high frequency of use of privately hired prosecutors in Oklahoma is indicated by the large number of cases involving that issue which reach the appellate courts. Comment, 12 OkLa. B.J. 1461 (1941.). Statistics released in Mathew, The Office and Dutres of the Director of Public Prosecutions 4 (1950), demonstrate that a large number of criminal prosecutions are undertaken by privately hired attorneys in England.

117. Chandler, Later-Day Procedures in the Sentencing and Treatment of Offenders in the Federal Courts, 37 VA. L. Rev. 825, 828-29 (1951); McGuire \& Holtzoff, The Problem of Sentence in the Criminal Law, 20 B.U.L. REv. 423, 424 (1940) ; Yankwich, Changing Concepts of Crime and Punishment, 32 GEo. L.J. 1, 17 (1943) ; Note, 64 YALE 'L.J. 260, 265-66 (1954).

118. See text at notes 74-76 supra.

119. To prohibit unjustified private prosecutions England originally relied on the grand jury, but ultimately abandoned this safeguard because juries in fact merely ratified 


\section{Operation of the Plan}

If the public prosecutor fails or refuses to prosecute, private prosecution should be permitted only where the court in its discretion considers the criminal action justified. The core of the plan is the limited substitution of judicial discretion for that of the public prosecutor. A summary hearing attended by all interested parties desiring representation, including the district attorney, would provide the court with necessary information. ${ }^{\mathbf{1 2 0}}$ The presumption supporting the propriety of the district attorney's decisions would permit the court to grant a petition only where circumstances so clearly warranted prosecution that reasonable men would not differ.

With such a plan in effect, the public prosecutor would remain primarily responsible for criminal prosecutions. The district attorney's acts would still be accorded a presumption of propriety although not the virtually irrebuttable one he now enjoys. ${ }^{121} \mathrm{He}$ would be given notice and an opportunity to justify his position to the court before any private petition could be granted. This procedure would not lead to harassment of the district attorney, since the court could always dismiss a groundless petition without notifying him, and would probably do so in many cases. Replacement of the district attorney would be in issue only if there were reason to believe he had abused his discretion by refusing to act, attempting to postpone a matter indefinitely or proceeding halfheartedly only to avoid a private prosecution. ${ }^{122}$ When the public prosecutor is called to contest a petition, his reasons for not acting should be given great weight. The court should be reluctant to interfere with the good faith

action taken by examining judges. Lieck, Abolition of the Grand Jury in England, $25 \mathrm{~J}$. Crim. L. \& Criminology 623, 624-25 (1935); Report on Prosecution, op. cit. supra note 8, at 34; see Hale v. Henkel, 201 U.S. 43, 59 (1906). The satisfactory operation of private prosecution in England attests to the sufficiency of court approval as a safeguard against unfounded and malicious actions. Lieck, supra, at 623.

120. Sufficient evidence may be adduced by affidavits to enable the trial court to determine whether a matter justifies criminal prosecution. The analogy to injunctions suggested in note 121 infra is applicable. There, affidavits or verified statements provide the basis for the court's decision. Ohio Oil Co. v. Conway, 279 U.S. 813 (1929); Benson Hotel Corp. v. Woods, 168 F.2d 694 (8th Cir. 1948). Hamilton Watch Co. v. Benrus Watch Co., 206 F.2d 738 (2d Cir. 1953), provides the additional suggestion that limited oral testimony might supplement affidavits to provide factual information necessary for the court's decision.

121. The public prosecutor's decisions would be reversed only for error or abuse of discretion. This test would be similar to that used by appellate courts in reviewing trial court determinations on the issuance of temporary restraining injunctions. That formula allows reversal on a showing of "clear proof that it [the lower court] has abused its discretion." Hamilton Watch Co. v. Benrus Watch Co., supra note 120, at 743 n.10; Love v. Atchinson, T. \& S.F. Ry., 185 Fed. 321, 331 (Sth Cir. 1911) ; cf. Benson Hotel Corp. v. Woods, supra note 120 , at 696-97.

122. The Pennsylvania statute allows the trial court to replace the public prosecutor for proceeding improperly as well as for neglect or refusal to act. PA. Stat. AnN. tit. 16, $\S 3432$ (Purdon 1930). Such a provision is necessary in order to prevent the district attorney from starting an action and conducting it haphazardly or delaying it in order to avoid private intervention. 
planning of the public prosecutor. For once private prosecution is allowed, the defenses of double jeopardy and res judicata would bar future state action. ${ }^{123}$ Finally, the district attorney should be able to intervene during a private prosecution to present evidence showing that the action should be dismissed.

Limitations on standing to prosecute would solve the objection that private prosecution will allow vigilantes or meddlers to try to enforce all laws. Private prosecution should be permitted only where the petitioning party has a cause of action in tort on the same set of facts, or where the crime is "open and notorious." This means that injury to a party could be redressed privately whenever a court thinks prosecution is justified, but crimes which injure society alone could be privately prosecuted only upon a showing that the crime threatens public confidence in law and order, or undermines the integrity of governmental institutions. Gambling and illegal liquor sales are the major crimes generally linked with such dangers, but other crimes may create similar problems. "Open and notorious" has been defined by the courts to mean manifested continually by visible signs, generally believed to be true, and publicly known. ${ }^{124}$ Crime has been called "open and notorious" when, for example, numerous newspaper articles exposed gambling and illegal liquor sales; when widespread solicitation by prostitutes occurred in public; and when 250 gambling machines were observed in 130 public places in one city. ${ }^{125}$

Other safeguards would restrain potential abuses in private prosecution. The danger of unfounded criminal actions would be reduced by the common law civil remedy for malicious prosecution. While most states grant the public prosecutor immunity from malicious prosecution suits, ${ }^{128}$ this protection is not

123. The private prosecutor acts in the name of the state. E.g., Taylor v. State, 49 Fla. 69, 38 So. 380 (1905) ; Commonwealth v. McHale, 97 Pa. 397 (1881) ; State v. Bartlett, $105 \mathrm{Me}$. 212, 74 At1. 18 (1909). There is little doubt that the accused is put in jeopardy when prosecuted privately, and a subsequent action by a public official would violate the right to immunity from double jeopardy. See Miller, Criminal Law 534-35 (1934). If issues or facts necessary to a conviction have been decided against the state in a prior action which has proceeded to final judgment, the doctrine of res judicata bars the second action. United States v. Oppenheimer, 242 U.S. 85 (1916) ; Coffey v. United States, 116 U.S. 436 (1886) ; United States v. Meyerson, 24 F.2d 855 (S.D.N.X. 1928).

124. Robinson v. United States, 33 F.2d 545 (W.D. La. 1929) ; People v. Salmon, 118 Cal. 303, 83 Pac. 42 (1905) ; Copeland v. State, 10 Okla. Crim. 1, 133 Pac. 258 (1913). The California and Iowa Supreme Courts have agreed that open and notorious crime occurs when there is a "demoralizing and debasing influence" on society. People v. Salmon, supra at 305, 83 Pac. at 43; State v. Marvin, 12 Iowa 499, 505 (1861). A similar formula was adopted in State v. Newnham, 17 S.W.2d 544 (Mo. App. 1929).

125. State ex inf. McKittrick v. Wymore, 345 Mo. 169, 132 S.W.2d 979 (1939). The conditions found in State ex inf. MicKittrick v. Graves, 346 Mo. 990, 144 S.W.2d 91. (1940), were labeled open and notorious by the Missouri Supreme Court in State ex inf. McKittrick v. Wallach, 353 Mo. 312, 323, 182 S.W.2d 313, 319 (1944). The "open and notorious" requirement has been found unsatisfied where public knowledge was limited and where the illegal activity was temporary. People v. Salmon, supra note 124; State v. Newnham, supra note 124 ; Copeland v. State, supra note 124.

126. See Note, 73 U. PA. L. Rev. 300 (1925). Most courts have deliberately chosen to leave abused defendants without civil recourse rather than restrict the prosecutor's free- 
available to private prosecutors. ${ }^{12 t}$ Assessment of trial costs plus defense counsel fees against the private prosecutor for actions instigated maliciously or without probable cause would further discourage unfounded actions. Several states currently impose this sanction by statute against malicious prosecuting witnesses. ${ }^{128}$ Another provision of the plan would prohibit discontinuance without the consent of the court under penalty of contempt. This would deter initiation of prosecutions for such purposes as forcing profitable civil settlements or collecting bills.

To establish a better balance between the discretion of the district attorney and the rights of society and the injured individual to have the criminal prosecuted, state legislatures should enact statutes providing substantially as follows:

1. A trial court may in its discretion, upon petition of any person, substitute an attorney hired by the petitioner to replace a public prosecutor for any criminal prosecution if

(a) the public prosecutor fails or refuses to prosecute the defendant or proceeds improperly, and

(b) the crime charged is open and notorious or the petitioner has a cause of action against the defendant in tort on the facts alleged.

2. A trial court shall not grant a petition without notifying the public prosecutor of the petition and allowing him reasonable time to answer it.

3. A private prosecution shall not be discontinued without permission of the trial court. At any stage of the proceedings the public prosecutor may present evidence showing why the private prosecution should be dismissed.

4. A private prosecutor shall receive reasonable compensation for legal services from county funds unless the trial court determines that the prosecution is malicious, in which case the petitioner shall pay the defendant reasonable compensation for legal services plus trial costs. ${ }^{129}$

dom. See, e.g., Yaselli v. Goff, 12 F.2d 396 (2d Cir. 1926) ; Griffth v. Slinkard, 146 Ind. 117, 44 N.E. 1001 (1896); Smith v. Parman, 101 Kan. 115, 165 Pac. 663 (1917); Watts v. Gerking, 111 Ore. 641, 222 Pac. 318 (1924). Contra, Skeffington v. Eylward, 97 Minn. 244, 105 N.W. 638 (1906); Leong Yau v. Carden, 23 Hawaii 362 (1916).

127. Potter v. Gjersten, 37 Minn. 386, 34 N.W. 746 (1887); Puutio v. Roman, 76 Mont. 105, 245 Pac. 523 (1926) ; Beuthner v. Ellinger, 90 Wis. 439.63 N.W. 756 (1895).

128. Ill. ANn. Stat. c. 38, § 717 (Smith-Hurd 1951); Iowa Code ANn. \$§ 769.10, 772.2 (1950) ; and ORE. REv. STAT. $\$ 156.290$ (1953) provide that if the prosecuting witness initiates a criminal action maliciously or without probable cause, the court may charge the cost to that witness. VA. CODE $\$ 19-233$ (1950); and W. VA. Code ANN. $\$ 6167$ (Supp. 1955) authorize the court to give judgment against the prosecuting witness for the costs of the accused if the prosecution was initiated maliciously or without probable cause.

129. This provision is not indispensable to an effective system of private prosecution. The desirability of eliminating costs as an obstacle to well-founded private prosecutions must be balanced against the possible detrimental effect of encouraging unfounded prosecutions which may arise because the state bears the cost. Since ample safeguards exist to prevent unfounded prosecutions, it is desirable that the state should pay prosecution fees so that legitimate criminal actions may be brought. 


\section{CONCLUSION}

Recent investigations have demonstrated that laxity in law enforcement threatens governmental institutions and public confidence in the law. Private prosecution can cover the areas of deficiency and still leave the bulk of the discretionary authority for criminal prosecutions with the district attorney. While the proposed statute might appear to be too novel an innovation. it must be remembered that all other attempts to restrain the district attorney's abuse of discretion have failed. Furthermore, the novelty of the plan is only a measure of the lack of knowledge Americans possess of the practical operation of such a system in England. It is interesting to note that both the English and the Americans have unfavorably evaluated the other's system of criminal law enforcement, suggesting strongly that the benefits of each may have been overlooked..$^{130}$ No doubt legislative approval of this statute will be slow to develop, but some optimism can be taken from the fact that thirty-four per cent of the public prosecutors responding to the questionnaire favored the proposed plan for private prosecution. ${ }^{131}$ The need to develop community responsibility for law enforcement is clear. With the courts as a fulcrum, private prosecution would balance the excesses of the district attorney's discretion with individual and community vigilance.

130. Private prosecution is opposed by United States courts on grounds that it would lead to criminal actions for personal gratification, private gain or malice. E.g., Oglesby v. State, 83 Fla. 132, 90 So. 825 (1922) (dictum) ; Meister v. People, 31 Mich. 99 (1875); Biemel v. State, 71 Wis. 444,37 N.W. 244 (1888). English objections to centralizing responsibility for criminal prosecution in a public official are summarized as follows: "Those opposed to the threatened innovation [public prosecution] pointed to the experience of other countries where, they charged, the control of the machinery for administering criminal justice had fallen necessarily into the hands of political parties and was being used by hordes of unscrupulous politicians to promote private or political ends. Private prosecutions ... were infinitely preferable ... to an enforcement of the criminal law which made the liberty of citizens dependent on the caprice or venom of party managers ...." Howard, The Conduct of Criminal Prosecutions in England [unpublished manuscript quoted in Moley, Politics and Criminal Prosecution 201 (1929)].

131. Questionnaire. See note 8 supra. 